\title{
Identification of Caligus parasites infesting Morone Labrax and its impact on fish health status and pathological alteration
}

\author{
Nevien Abdelkalek ${ }^{1}$, Rehab Abd EL Maged ${ }^{2}$, Hanaa Ali $^{3}$, Neveen Satour ${ }^{4}$ \\ ${ }^{1}$ Department of Internal medicine, Infectious and fish diseases, Faculty of Veterinary Medicine, Mansoura University, Egypt. \\ ${ }^{2}$ Department of Parasitology, Animal Health Research Institute (AHRI), Agriculture Research center (ARC), P.O. Box 246 Dokki, 12618 - Giza, Egypt. \\ ${ }^{3}$ Department of of pathology, Animal Health Research Institute (AHRI), Agriculture Research center (ARC), P.O. Box 246 Dokki, 12618 - Giza, Egypt; \\ Mansoura branch, Egypt. \\ ${ }^{4}$ Department of Parasitology, Animal Health Research Institute (AHRI), Agriculture Research center (ARC), P.O. Box 246 Dokki, 12618 - Giza, Egypt; \\ Alexandria branch, Egypt.
}

\section{ARTICLE HISTORY}

\section{ABSTRACT}

Received: 03.01.2021

Revised: 07.02.2021

Accepted: 07.02.2021

Address correspondence to Nevien Abdelkalek; Tel. +201010573552; E-mail: nevienabdelkhalek@gmail.com

\begin{abstract}
Objective: The present study was aimed to investigate sea lice infestation including morphometric, molecular identification, disease prevalence and pathological tissue alterations in wild Sea bass (Morone Labrax) naturally collected from Ezbet Elborg, Damietta province, Egypt from October 2018 to end of August 2019.

Design: Descriptive study

Fish: 120 wild seabass (Morone Labrax)

Procedures: The collected fish from Ezbet Elborg area, Damietta province, Egypt were clinically and parasitological investigated for the prevalence of sea lice parasite with molecular identification of the collected parasite samples with study of the pathological alteration of the affected tissue.

Results: The study revealed that 48 fish (40\%) of the examined fish were infested with Caligus clemensi, while the higher prevalence recorded during summer season (57\%) followed spring (33\%), autumn (10\%) and no recording during winter. The molecular identification using 18-S rDNA was done with phylogenetic analysis compared with the previously recorded caligus species on database confirming the same results of parasitology. Histopathological examination of gills, buccal cavity revealed that the gill arch contained congested blood vessels beside edema, hemorrhage and inflammatory cells infiltration due to parasitic infestation.

Conclusions and clinical relevance: Caligus infestation in wild sea bass caused by Caligus clemensi lead to mortalities due to pathological tissue alterations in gills and buccal cavity.
\end{abstract}

Keywords: Wild Morone labrax, Caligus clemensi, molecular identification, histopathological examination

\section{INTRODUCTION}

Fish are considered one of the most important sources of animal proteins all over the world. Marine fish are preferable than freshwater fish as the former are rich in phosphorus and iodine which are essential for cell metabolism. Parasitic copepods are common crustacean parasites infesting fresh, cultured and wild marine fish [1] Members of Caligidae are the most commonly reported species infesting marine fish known as sea lice, comprises 28 genera and more than 400 species [2]. Genus caligus is the most species within caligidae, according to their mouthparts, the caligids have tubular mouth, their mandibles are flat, long blades with distal end carrying arrow of teeth on one margin [3].

The sea bass is euryhaline (0-40 ppt salinity) and eurythermal $\left(2-32{ }^{\circ} \mathrm{C}\right)$ and is often found foraging in estuaries and lagoons from spring to fall, especially at the juvenile stage. During winter, juvenile and adult sea bass migrate from the coastline to deeper waters, where the temperature is more stable, as they prefer temperatures above $9-10{ }^{\circ} \mathrm{C}$ [4]. Sea lice is commonly used to refer to several species of marine ectoparasitic copepods of the family Caligidae (order Copepoda: suborder Siphonostomatoida), prevalence of it increases with higher temperatures [5]. Moreover, sea temperature affects the occurrence and life cycle of caligids [6], the feeding behavior of larval stages may be planktotrophic or lecithotrophic [7], the planktons need sun light for photosynthesis and napulius needs planktons to survive so the caligus spp is believed to live with sufficient light. Caligid parasites present in the environment on wild fish populations will most probably infect the new caged hosts and re-infect wild fish populations. Members of Caligidae are the most commonly reported species infesting marine fish known as sea lice, comprises 28 genera and more but the main difference between the Caligus species are the relative sizes of the four component body parts, particularly the shape and size of the genital complex, length and segmentation of abdomen [8]. 
Parasitic infestations represent the majority of the known infectious diseases affecting fish, they cause mortality, deformity, weight loss and different clinical abnormalities among the affected fish [9]. Parasitic copepods feed on host mucous, tissues, and blood. In addition, their attachment and feeding activities are responsible for any primary disease that develops [10]. In disease situations, death may be caused by the development of secondary infections exacerbated by stress and the formation of open wounds, osmoregulatory failure, and in the case of the gills, respiratory impairment [11-12-13]. In many cases, increased fibroplasia and spongiosis is noticed within dermal collagenous connective tissue [14]. Parasites of the gills can cause irritation, leading to hyperplasia and increased mucous production, which result in decreased respiration and ion exchanging capabilities [15-16].

\section{Materials and Methods}

\subsection{Sample Collection}

A total number of 120 wild seabass (Morone Labrax) fish suffering parasitic infestation with recorded mortality were collected during October 2018 to end of August 2019 from naturalfish collection areas in Ezbet Elborg area (wild fish), Damietta province, Egypt. The collected fish were transported to parasitology laboratory, Animal Health Research Institute, Mansoura branches, Egypt in polyethylene bags. The lengths and body weights of examined fish were ranged from $30-60 \mathrm{~cm}$ and $200-440 \mathrm{~g}$ respectively. The collected fish were examined clinically for postmortem lesions according to [17].

\subsection{Parasitological examination}

The caligus parasites were collected using a fine brush and special needle. Placed into petri-dish containing normal saline and washed several times to get rid of mucus preserved and cleared in lactophenol and mounted by polyvol then, left to dry according to [18-19]

\subsection{Molecular identification}

\subsubsection{DNA extraction, amplification and sequencing of} 18srRNA gene

DNA extraction for the isolated copepods was conducted according to the protocol of [20], where the concentration of DNA and purity was determined using Quawell nanospectrophotometer (Q5000 UV-VIS) (USA). The integrity of DNA was checked using $2 \%$ agarose gel electrophoresis. For amplification of 18srRNA gene of isolated copepods, an alignment of sequences of Lepeophtheirus species as follow: (JX896389.1 Lepeophtheirus frecuens, JX896386.1 L. chilensi, AF208263.1 L. salmonis, JX896402.1 L. yanezi, JX896400.1 L. zbigniewi, DQ123831.1 L. hospitalis, DQ123830.1 L. parvicruris, KR048780.1 L. parviventris voucher) and caligus species as followed: (MF077737.1 caligus curutus, EF088406 C. centrodonti, EF088410.1 C. gurnardi, KC569364.1 C.fugu, DQ123833.1 C.clemensi, EF088409.1 C. elongates, KR048777.1,
C. puctatus, EF088405.1 C. belones, EF088412.1 C. quadratus, KP681600.1 C. rogercresseyi), where a primer sequence for caligadae was manually designed after the alignment; CalF: CAATGATCGAAGATCGAGGTAGTG,

CalR: TCTTTGGTTTCCCGGAAGCT. PCR cycling condition was conducted with $2 x$ master mix provided from EmeraldAmp MAX premix (Takara, Japan) and $20 \mathrm{pmol}$ primers with initial denaturation of $95^{\circ} \mathrm{C} / 5 \mathrm{~min}$ that was followed by 40 cycles of denaturation $\left(95{ }^{\circ} \mathrm{C} / 50 \mathrm{sec}\right)$, elongation $\left(72{ }^{\circ} \mathrm{C} / 45 \mathrm{sec}\right)$ and annealing $\left(56^{\circ} \mathrm{C} / 30 \mathrm{sec}\right)$ and the reaction was terminated with final elongation $\left(72^{\circ} \mathrm{C} / 9 \mathrm{~min}\right)$. After the termination of PCR, gel electrophoresis was performed using 40이 of PCR product on $1.5 \%$ agarose gel electrophoresis for visualization of PCR product, where the expected amplicon size of PCR product was standardized against 100bp DNA ladder (Gene ruler, ThermoFisher Scientific). The visualized PCR product was excised using sterilized clean scalpel and transferred to sterilized clean epindorf tube for gel extraction protocol using GeneJET gel extraction kit (ThermoFisher Scientific). After gel purification, sequencing for PCR product was determined by ligating the PCR product with cloning vector (pTZ57R/T) (ThermoFisher Scientific). Clone containing DNA insert was sequenced using forward primer M13/pUCF: GTAAAACGACGGCCAGT and reverse primer M13/pUCR: CCAGTATCGACAAAGGAC. Sequencing was performed using automated sequencer (ABI 377) (Applied biosystem) according to manufacturer instructions.

\subsection{Histopathological examination}

The affected fish tissue with by caligus parasites including gills and oral cavity were dissected out and fixed in $10 \%$ phosphate buffered formalin, then dehydrated in ascending grades of alcohol and cleaned in xylol, then embedded in paraffin wax, cut into thin 5um sections and floated on warm water. The sections were left from the water path on microscope slides, coated with Myers albumin, allowed to dry thoroughly and stained by hematoxylin eosin according to [21]

\section{RESULTS}

\subsection{Clinical examination}

The clinical signs in the naturally infested wild fishes (Morone labrax) revealed congestion of gills, erosions on hard palate with presence of caligus parasites with no pathognomonic internal clinical abnormalities. Presence of both male and female adult stages of Caligus clemensi on hard palate and gills of the infected fish (figure 1)

\subsection{Prevalence of Caligus clemensi in seabass (Morone labrax) fish}

Table (1) showing the seasonal prevalence of Caligus clemensi parasite in wild seabass from October 2018 to end of August 2019 in Ezbet Elborg, Damietta province, Egypt. The study revealed that 48 fish (40\%) of the examined fish were infested 
with Caligus clemensi, while the higher prevalence recorded during summer season (57\%) followed spring (33\%), autumn $(10 \%)$ and no recording during winter.

Table 1. Seasonal prevalence of sea lice Caligus clemensi parasite among wild seabass (Morone labrax).

$\begin{array}{llll}\text { Season } & \text { Examined } & \begin{array}{l}\text { Infected fish with } \\ \text { Calligus clemensi }\end{array} & \% \text { of infected } \\ \text { Autumn } & 30 & 3 & 10 \% \\ \text { Winter } & 5 & 0 & 0 \\ \text { Spring } & 15 & 5 & 33 \% \\ \text { Summer } & 70 & 40 & 57 \% \\ \text { Total } & 120 & 48 & 40 \%\end{array}$
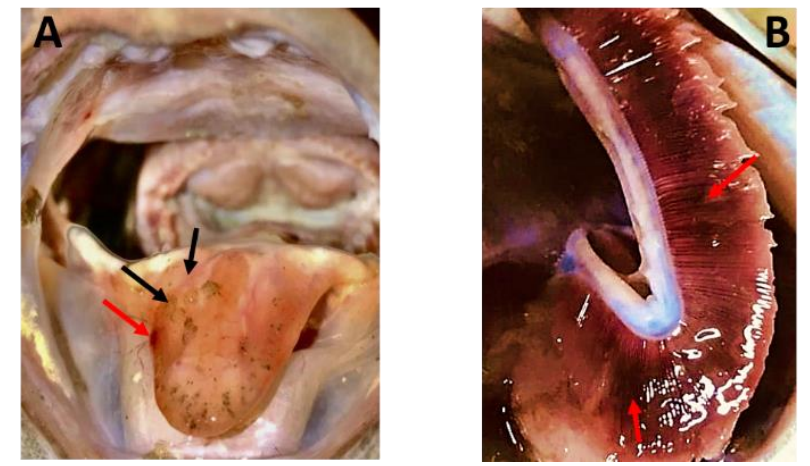

Figure 1. Macroscopic detectionshowing Presence of both male and female adult stages of caligus clemensi on hardpalate of the infected Morone labrax (black arrow) causing erosions and congestion on tongue (red arrow) (A). Congestion of gills Sea bass (Morone labrax) infested with Caligus clemensi parasite causing erosions of gills (red arrow) (B)

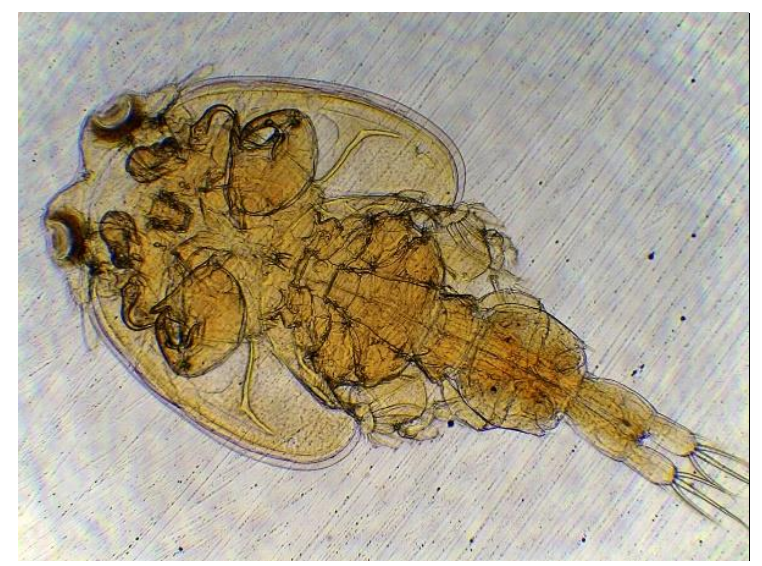

Figure 2. Microscopical identification of adult male caligus clemensi (x40).

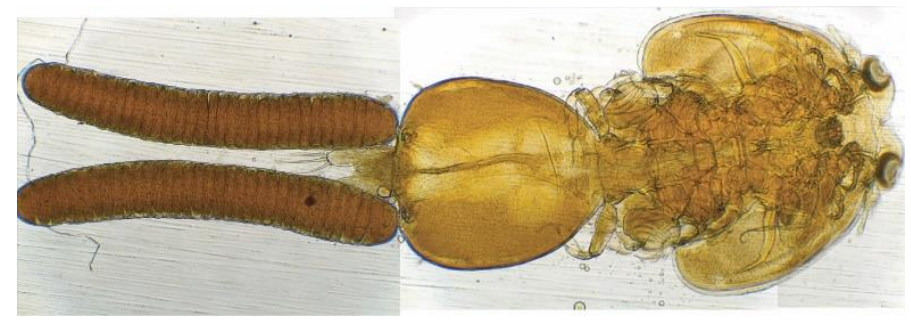

Figure 3. Microscopical identification of adult female caligus clemens(x40).
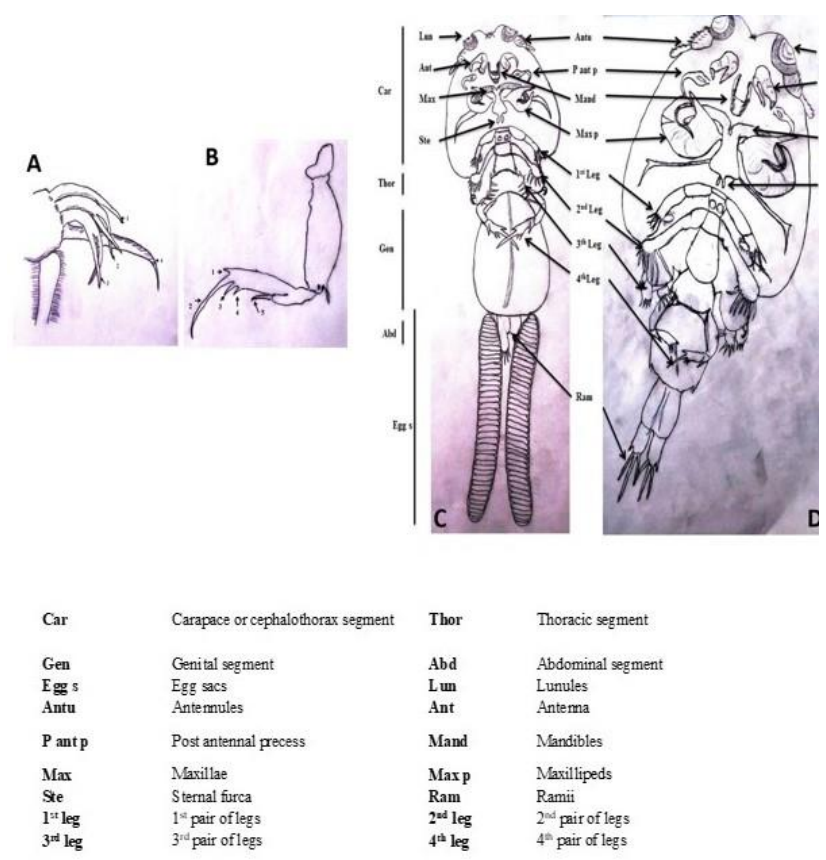

Figure 4. Line drawing of male and female.

\subsection{Morphological description of parasites}

Caligus clemensi Parker \& Margolis, 1964 Kingdom: Animalia Class: Crustacea Subfamily: Caliginae, Family: Caligidae Number of parasitological examined parasites: 25

Caligus clemensi either male (Fig 2) or female (Fig3) are identified by $1^{\text {st }}$ and $4^{\text {th }}$ legs. The distal margin of $1^{\text {st }}$ pair of leg are charectrized by presence of setae 1 and 4 undivided and unarmed, setae 2 and 3 bifid (fig $4 \mathrm{~A}$ ) while $4^{\text {th }}$ pair of legs consists of 3 segments bearing bristilles and 5 setae, 4 seta found in the destal end of the last segment, one in the next. (fig 4 B). On the other hand, male and female were differ in some morphological findings (Figures $4 \mathrm{C}$ and $\mathrm{D}$ respectivly). Females was ovate carapace but not longer than remaining body. Frontal plate was broad with anterior grouve. Free thorathic segment was very short and small approximately. Genital segment was oval with curved lateral adges and exceed in length the half carapace. Abdomen was short and somewhat enlarged towards posterior end. Caudal rami were one short and three long with alittle bent and each had bristiles. Two long egg sacs about the same length of body were present. Body ranged from $10-14 \mathrm{~mm}$ long (fig $4 \mathrm{C}$ ). While male had very broad carapace with enlargement towards posterior end. Free thotacic segment was short. Genital segment was less broad with rounded lateral adges. Abdomen consistes of one segment. were one short and three long with alittle bent and each had bristiles.. Body ranged from 12- $24 \mathrm{~mm}$ long (fig $4 \mathrm{D}$ ). 


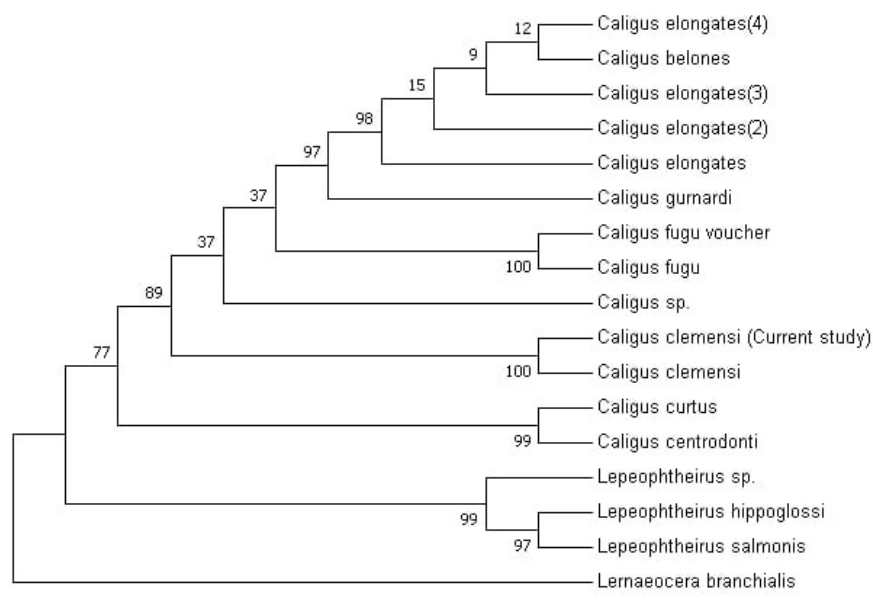

Figure 5. Phylogenetic tree of the $18 \mathrm{~S}$ rRNA gene obtained from C. clemenis.

\subsection{Molecular identification}

The sequencing result of $C$. clemensi produced $1135 \mathrm{bp}$ and had been deposited on genbank with accession number of (MT151385) that was checked with similarity index on genbank and gave $99.74 \%$ similarity index with C. clemensi isolated from chum salmon in Canada. As shown in figure 5, phylogenetic analysis showed the presence of two clades; Clade $A$ that contained all caligids species according to Blast result and Clade B that contained all Lepeophtheirus species. Lernaeocera branchialis is assigned as an outgroup. Clade A was divided into two sub-clades; Clade Al and Clade All. Clade Al was consisted of All caligids species except $C$. curtus and $C$. centrodonti (Clade All). The current $C$. clemensi showed high similarity index and close relationship between $C$. clemenis isolated for chum salmon and formed a specific sub sub-clade with the other C.clemensi species.

\subsection{Histopatholothological finding}

Parasites are stacked on gill filaments with partial or complete sloughing of their lamellar epithelium which results in denuded filaments (fig.6-1). Sometimes hyperplastic secondary lamellar epithelium in the adjacent area which led to fusion of the filaments were encounted thickened filaments by numerous inflammatory cells and edema beside dilated capillaries were observed. Fragments from the parasite were detected between primary filaments with ulceration and distortion of the adjacent filaments (fig.6-2). Sometimes, heavy parasitic infestation with atrophy, distortion and blunting of the gill filaments could be seen (fig.6-3). The base of primary filaments was covered by sheath from hyperplastic lamellar epithelium. The gill arch contained congested blood vessels beside edema, hemorrhage and inflammatory cells infiltration mainly eosinophil, granular cells in their necrotic muscles (Fig.64). Oral cavity showed erosion or ulceration of their lining epithelium beside hyperplastic mucus secreting cells beside numerous inflammatory cells infiltration mainly lymphocytes (fig.6-5 and 6-6).
Figure 6. Photomicrograph from gills and oral cavity of Morons Labarax section
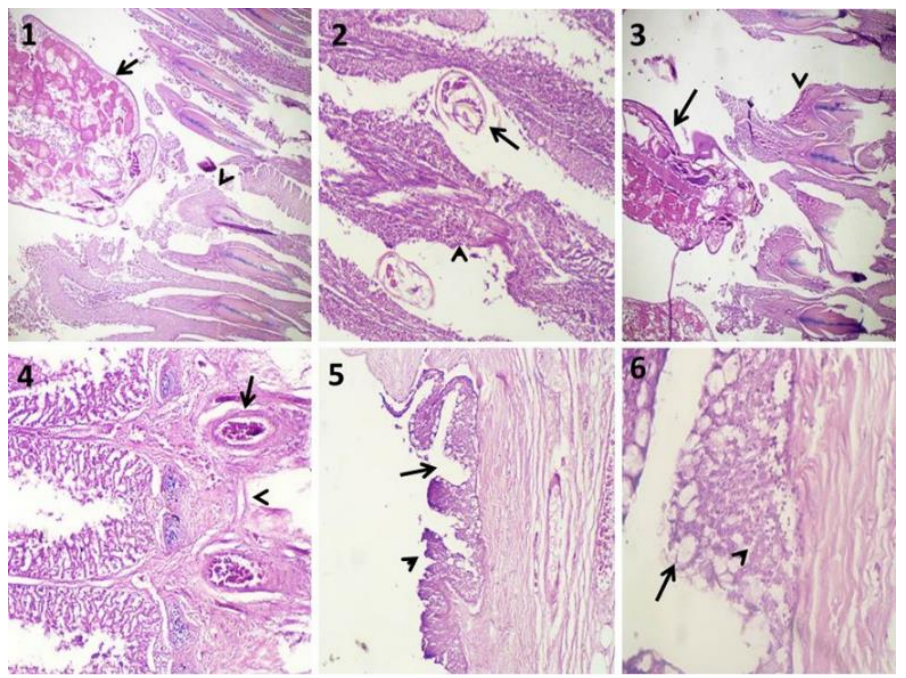

stained with H\&E. 1: Gills showing parasite (arrow) sticked on gill filaments with sloughing of the adjacent lamellar epithelium (arrow head) x100. 2: Gills showing fragments of parasitic elements (arrow) with ulceration of primary filaments (arrow head) x100. 3: Gills showing numerous parasites (arrow) with atrophy and distortion of the adjacent filaments $\times 100.4$ : Gill arch showing congested blood vessels (arrow) with necrosis, odema and leukocytes in the muscles (arrow head) $\times 100.5$ : Oral mucosa showing erosion and ulceration (arrow) of their epithelium $\times 100.6$ : High power of the pervious figure to show numerous mucus secreting cells (arrow) and inflammatory cells in the mucosa (arrow head) x400.

\section{DISCUSSION}

Damietta province is one of the most important area for production of fish in Egypt, caligus is considered important pathogen infesting marine fish. The aim of work is the determination of prevailing Caligus parasite disease affecting Morone Labrax fish and their impact on the fish health as well as the study the molecular of parasite. The main clinical signs observed in infested Morone labrax with crustacean infestations were excessive mucus production, erosion and ulceration. These signs are as a result of the attachment by means of second pair of the antennae which were inserted into the host epidermal tissue which caused the low respired oxygen of destructed gill epithelium of the parasites. These results are in agreement with those reported by [8-22]. Focal hemorrhage, abrasions on hard palate. These may be attributed to the parasites penetration of hard palate for fed and facilitate the invasion of the opportunistic microorganisms. These results are in agreement with that reported by [23-24]. Emaciation was recorded in M. labrax may be due to crustacean infestation which reduce fish appetite and became off food, this agreed with [25-22]. Morone labrax was infested with Caligus parasite with a percent of $40 \%$, the result agreed with that given by [26] from Suez Canal area, while higher than recorded from Port Said province (19\%) by [27] and lower than reported by [24] 
who reported (47\%) from different areas of Suez Canal (Ismailia province). The difference in prevalence of caliguse infestation may be reported due to feeding of fish, light, temperature and degree of water pollution with different locality. This study showed the higher prevalence during summer $(57 \%)$ followed by spring $(33 \%)$, autumn $(10 \%)$ and no recording during winter, the present findings nearly agreed with previous results reported by [28-29-16] in which they recorded the summer season as the highest infection rate and no recording during the winter season, the variation between seasons may be attributed to seabass were investigated from spring to summer [30], the change of tempreature and golbal warming that affected prevalence of sea lice with changed tempreture [5].

Seabass infested with different species of caligus, in our study caligus clemenis is recorded while recorded by [31] from adult Pacific salmon in Canada, also [10] said that caligus clemenis was the major species that able to create problem to salmonid culturing industry in few countres within American.

Caligus clemenis was parasitological identified by $1^{\text {st }}$ and $4^{\text {th }}$ legs. The distal margin of $1^{\text {st }}$ pair of leg are charectrized by presence of setae 1 and 4 undivided and unarmed, setae 2 and 3 bifid, while $4^{\text {th }}$ pair of legs consists of 3 segments bearing bristilles and 5 setae, 4 seta found in the destal end of the last segment, confirmed by [32-33-34], male and female were differ in females was ovate carapace but not longer than remaining body, while male had very broad carapace with enlargement towards posterior end, this agreed with [35].

The present study showed histopathological lesions mainly in gills and oral cavity. Gills lesions were characterized by complete sloughing of their lamellar epithelium and necrosis of the underlying musculature with numerous inflammatory cells. In advanced stages hyperplastic secondary lamellar epithelium and edema beside dilated capillaries. Similar histopathological pictures were recorded by [16- 36]. These lesions may be attributed to the parasites attachment and feeding activity causing massive destruction of respiratory epithelial cells [9].[37]reported that degenerative and necrotic changes in the epithelial cell with hyperplasia of fin filaments associated with chronic inflammatory cells infiltration .. The changes recorded in the oral cavity in the present study came in parallel with that recorded by [38-39]. The increase of phagocytic cells and mucous cell hyperplasia in response to fish parasitizes as defense mechanism for elimination of parasites. This result was compatible with that recorded by [16].

\section{Conflict of Interest}

No Conflict of Interest

\section{Animal ethics permission committee}

This study was followed the guidelines of Committee of Animal Welfare and Research Ethics, Project management and planning code number 13429 Ser.19,
Animal Health Research Institute (AHRI), Agriculture Research center (ARC), P.O. Box 246 Dokki, 12618 - Giza, Egypt.

\section{Authors' Contribution}

All authors are equally contributed

\section{REFERENCES}

[1] Suárez-Morales E, Ho J, Santana-Piñeros A. Caligus tenuifurcatus Wilson, 1937 (Copepoda, Siphonostomatoida), a parasite of centropomid and lutjanid teleosts from a coastal system of the Mexican Pacific. Acta Parasitol 2008;53: 397-403. https://doi.org/10.2478/s11686-008-0051-6

[2] Boxshall GA, Halsey, SH. An introduction to copepod diversity. The Ray Society 2004, London, 966pp. ISBN 0-903874-31-8. https://doi.org/10.1645/0022-3395-91.6.1512

[3] Kabata Z. Mouth and mode of feeding of Caligidae (Copepoda) parasites of fishes at determined by light and scanning electron microscopy. J Fish Res Boa Canada 1974; 31:1583-1588. https://doi.org/10.1139/f74-199

[4] Pickett GD, Pawson MG. Seabass - Biology, Exploitation and Conservation. Chapman \& Hall, London, 1994; ISBN $0 \begin{array}{lllll}4 & 40090 & 1\end{array}$ https://doi.org/10.1002/aqc.3270050207

[5] Johnson S, Jakob E. 3.2. 14 Sea Lice Parasitism. Fisheries and Oceans Canada. Canada. 2012 Jun;250:756-077.

[6] Morton A, Routledge R, Peet C, Ladwig A. Sea lice (Lepeophtheirus salmonis) infection rates on juvenile pink (Oncorhynchus gorbuscha) and chum Oncorhynchus keta) salmon in the nearshore marine environment of British Columbia, Canada. Can J Fish Aquat Sci 004 1;61:147-57. https://doi.org/10.1139/f04-016

[7] Rohde K, editor. Marine parasitology. Csiro publishing; 2005 Sep 13. https://doi.org/10.1079/9780643090255.0000

[8] Kabata, Z. Copepods parasites on ¿shes. In Copepods parasitic on ¿shes, New series (ed. D.M. Kermack et al.), 1992; pp. 1-264. Oegstgeest: Universal Book Services, Netherland.

[9] Eissa IA. Parasitic fish diseases in Egypt. Dar El-Nahda El-Arabia Publishing, Egypt. 2002;32:149-60.

[10] Johnson SC, Bravo S, Nagasawa K, Kabata Z, Hwang J, Ho J, Shih CT. A review of the impact of parasitic copepods on marine aquaculture. Zool stud. 2004;43:229-43.

[11] Pike AW, and Wadsworth SL. Sea lice on salmonids: their biology and control. Adv Parasit 1999; 44: 233-337. https://doi.org/10.1016/S0065308X(08)60233-X

[12] Bowers JM, Mustafa A, Speare DJ, Conboy GA, Brimacombe M, Sims DE, Burka JF.The physiological response of Atlantic salmon, Salmo salar L., to a single experimental challenge with sea lice, Lepeophtheirus salmonis. J Fish Dis 2000; 23: 165-172. https://doi.org/10.1046/j.13652761.2000.00225.x

[13] Finstad B, Bjorn P, Grimnes A, Hvidsten N. Laboratory and field investigations of salmon lice Lepeophtheirus salmonis (Krøyer) infestation on Atlantic salmon (Salmo salar L.) post-smolts. Aquacult Res 2000; 31: 795-803. https://doi.org/10.1046/j.13652109.2000.00511.x

[14] Ragias, VD, Tontis and Athanassopoulou, F. Incidence of an intense Caligus minimus Otto 1821, C. pageti Russel, 1925, C. mugilis Brian, 1935 and C. apodus Brian, 1924 infection in lagoon cultured Seabass (Dicentrarchus labrax L.) in Greece. Aquaculture, 2004; 242: 727-733. https://doi.org/10.1016/j.aquaculture.2004.08.019

[15] Noor El-Deen Al. Comparative studies on the prevailing parasitic diseases in monosex tilapia and natural male tilapias in Kafr El Sheikh Governorate fish farms (Doctoral dissertation, Ph. D. Thesis, Fac Vet Med, Kafr El-Sheikh University).

[16] Noor El-Deen Al, Abeer EM, Azza, HMH. Field Studies of Caligus parasitic Infections among Cultured Seabass (Dicentrarchus labrax) and Mullet (Mugil cephalus) in Marine Fish Farms with Emphasis on Treatment Trials. Global Veterinaria 2013; 11: 511-520. 
[17] Noga EJ. Fish diseases: diagnosis and treatment. Copyright MosbyyearBook 1996; Watsworth publishing, second edition, Co., U. S. A.

[18] Pritchard MH, Kruse GOW. The collection and preservation of animal parasites. Univ, Lincolin and London 1982; pp 141.

[19] Moravec F. Parastic nemtodes of freshwater fishes of Europ. Kluwer Academic Publishers 1994. Dordrecht Nether land.

[20] Cornils A, Held C. Evidence of cryptic and pseudocryptic speciation in the Paracalanus parvus species complex (Crustacea, Copepoda, Calanoida). Frontiers in Zoology 2014; 11:19. https://doi.org/10.1186/1742-9994-1119

[21] Carleton M, Drury Y, Wallington E, Carmeron H. Carleton histological technique 1967 4thEd. Oxford Univ. Press, New York, Toronto.

[22] Eissa IAM, El-Lamie M, Zaki M. Studies on Crusteacean Disease of seabass, Morone labrax, in Suez Canal, Ismaillia Governorate. Life Sci j 2012, 9: 512518.

[23] Noor El-Deen AE, Abd El Hady OK, Shalaby SI, Zaki SM. Field studies on Caligus disease among cultured Mugil cephalus in brackish water fish. Life Science journal, 2012; 9: 733-737. (ISSN: 1097 -8135).

[24] Woo PTK. Fish diseases and disorders. CAB, Int. Wallingford, Oxon, Uk 2006; pp: 482-565.

[25] NagasawaK.Sealice, Lepeophtheirus salmonis and Caligus orientalis (Cope poda: Caligidae), of wild and farmed fish in sea and brackish waters of Japan and adjacent regions: a review. Zool Stud 2004; 43(2): 173- 178.

[26] Youssef EM. Caligus lagocephali, Pillai, 1961 (Copepoda: Caligida:Siphonostomatid) from Morone labrax (as a new host) in Suez Canal area, EVMSPJ 2015; 11:95-98. https://doi.org/10.21608/evmspj.2015.37960

[27] Eissa I, Derwa H, El Lamie M, El Raziky E. Studies on Crustacean Diseases of Seabass and White grouper fishes in Port Said Governorate. SCVMJ 2016 30;21:143-58. https://doi.org/10.21608/scvmj.2016.62775

[28] Eissa IA, El-lamie MM, Aly SM, Sallam NH. Studies on the Prevailing Parasitic Diseases in Some Marine Fishes. Egyptian Veterinary Medical Society of Parasitology Journal (EVMSPJ) 2017 1;13:64-77. https://doi.org/10.21608/evmspj.2017.37769

[29] Abdel Alim AF, Abdel Fadil H, Said AA, Edress N. High efficacy of methylene blue, potassium permanganate and copper sulphate in treatment of ectoprotozoal infestation in Tilapia nilotica fish. Assiut Vet Med J 1995;33:82-82.

[30] Dufour V, Cantou M and Lecomte F. Identification of seabass (Dicentrarchus labrax) nursery areas in the north- western Mediterranean Sea. Journal of the Marine Biological Association of the UK 2009; 89(07). https://doi.org/10.1017/\$0025315409000368

[31] Beamish RJ, Neville CM, Sweeting RM and Ambers N. Sea lice on adult Pacific salmon in the coastal waters of Central British Columbia, Canada, Fish Res 2005; 198-208. https://doi.org/10.1016/j.fishres.2005.06.007

[32] Kabata Z. Mouth and mode of feeding of Caligidae (Copepoda) parasites of fishes at determined by light and scanning electron microscopy. J Fish Res Boa Canada 1974; 31:1583-1588. https://doi.org/10.1139/f74-199

[33] Kabata Z. Copepoda and Branchiura. Pages 3-127 in L. Margolis, and Z. Kabata, editors. Guide to the Parasites of Fishes of Canada. Part II Crustacea. Canadian Special Publication of Fisheries and Aquatic Sciences 1988; 101:84. https://doi.org/10.1139/z88-027

[34] Parker RR, and Margolis L. A new species of parasitic copepod, Caligus clemensi sp. nov. (Caligoida, Caligidae) from pelagic fishes in the coastal waters of British Columbia. JFRBC 1964; 21:873-889, figs. 1-12. https://doi.org/10.1139/f64-085

[35] Johnson SC and Albright LJ. Lepeophtheirus cuneifer Kabata, 1974 (Copepoda: Caligidae) from seawater-reared rainbow trout, Oncorhynchus mykiss, and Atlantic salmon, Salmo salar, in the Strait of Georgia, British Columbia, Canada. Can J Zool 1991b; 69:1414-1416. https://doi.org/10.1017/\$0025315400051687

[36] Costello MJ. Ecology of sea lice parasitic on farmed and wild fish. Trends Parasitol 2006; 22: 475-483. https://doi.org/10.1016/j.pt.2006.08.006

[37] AL-Darwesh AA, Al-Shabbani M and Faris B. Diagnostic and pathological study of argulus japonicas in goldfish (carassius auratus) GJBB 2014;3: 384.
[38] Eissa IAM. Parasitic fish diseases in Egypt. Dar El- Nahda El- Arabia publishing 2006, 2 Edit. 23 Abd El- Khalek Tharwat St. Cairo, Egypt, pp: $161-$ 181.

[39] Cruz-Lacierda ER,Yamamoto A and Nagasawa K. Seasonal occurrence of Caligus spinosus and, Parabrachiella seriolae (Copepoda) parasitic on cagecultured yellowtail (Seriolaquin queradiata) at fish farm in western Japan. Bull Eur Assoc Fish Pathol 2011; 31: 58-65. 